\title{
Motivational Factors Impacting the Use of Citizen Reporting Applications in Saudi Arabia: The Case of Balagh Application
}

\author{
Muna M. Alhammad ${ }^{1}$, Layla Hajar ${ }^{2}$, Sahar Alshathry $^{3}$, Mashael Alqasabi ${ }^{4}$ \\ Management Information System Department, King Saud University, Riyadh, Saudi Arabia
}

\begin{abstract}
Citizen reporting applications are considered a new approach for interaction between government authorities and citizens. Citizen reporting applications are implemented to collectively gather information from citizens on issues related to public interest such as accidents, traffic violations, and commercial frauds. Through utilizing citizen reporting applications, citizens are able to provide information about incidents efficiently and conveniently to the local authorities via mobile applications that are designed for these specific purposes. For such applications to be successful, citizens' willingness to participate continually and to become daily users of these applications is required. This paper applies the selfdetermination theory to investigate the factors that encourage citizens to participate in citizen reporting applications. In this study, the factors impacting behavioural intention to use the applications are divided into two categories. First, intrinsic motivation factors that include self-concern, social responsibility, and revenge. Second, extrinsic motivation factors that include output quality and rewards. The study empirically surveyed 297 Saudi citizens from different age groups. The partial least square (PLS) approach validates the research model. Findings reveal that output quality, revenge, and self-concern are significantly associated with citizens' motivations to use the applications, whereas rewards and social responsibility do not significantly influence citizens' motivations to engage with such applications. This study contributes theoretically by enriching literature on the identification of the factors behind user's engagement in citizen reporting applications. It also contributes practically by supporting the developers of citizen reporting applications to consider these factors when designing and marketing this kind of application.
\end{abstract}

Keywords-Crowdsourcing; self-determination theory; intrinsic motivation; extrinsic motivation; citizens reporting

\section{INTRODUCTION}

Crowdsourcing is the utilization of various potential external contributors to accomplish a certain task via an online platform [1]. There are two types of users in crowdsourcing [2]. The first type is individuals or organizations who request tasks or assistance in solving problems. The second type is crowd members who offer to contribute to the problem solution.

Due to the unprecedented advancement of the Internet and online technologies, the process of crowdsourcing has become truly a phenomenon. Crowdsourcing applications are being used in several fields around the globe, such as in scientific research, education, business, and medicine [3]. Also, several countries employed crowdsourcing applications as part of their disaster relief efforts. During the Colorado wildfires in 2012 and 2013, crowdsourcing played a significant role in allocating resources to the affected areas [4]. Such applications are also being used to report health cases and deploy disaster relief services instantaneously, such as during the cholera outbreak in Haiti in 2010, the dengue outbreak in Thailand and Indonesia in 2010, and most recently, during the COVID-19 pandemic in 2020 [4]. Several countries have developed crowdsourcing applications as an emergency response to the spread of COVID-19. For example, to decrease the spread of the disease, data on symptoms of COVID-19 were collected and analysed using smartphones to wirelessly crowd-map positive cases [4].

COVID-19 is a highly contagious disease that has forced several governments to impose quarantine restrictions around countries [5]. Saudi Arabia was one of the affected countries. The Saudi government, like many other governments, implemented several countermeasures to reduce the outbreak of COVID-19 among its citizens. For example, travellers who came directly or indirectly from China were examined in the Saudi airports and any recent travel to China needed to be declared into immigration and passport offices [6]. Despite the significant impact of these countermeasures, studies [6] have shown that these countermeasures would not be fully effective in preventing the spread of the virus. Further countermeasures were applied and a quarantine was imposed by the Saudi government to control the pandemic effectively. Educational institutions at all levels transformed all their activities online, regular face-to-face meetings were switched to online meetings and attendance to workplaces were suspended and telework was applied instead [7]. Saudi authorities emphasized the importance of social distancing and believed that it is a key measure to minimize the outbreak of the virus. Therefore, the Saudi government decided to close restaurants, grocery stores and shopping malls and allowed only home delivery services through websites or mobile applications [7]. As a result, ecommerce in Saudi Arabia increased by 400 per cent in April and May, 2020 causing 30,000 complaints about shipping delays [8]. These complaints were filed by citizens and handled by the Ministry of Commerce through an application called "Balagh App" [9]. Balagh app is a citizen-reporting application that was launched by the Ministry of Commerce to enable citizens to file commercial violations or frauds. The awareness towards citizen-reporting applications in Saudi Arabia, such as "Balagh app", has increased during the curfew due to the increased number of issues related to the delayed or missing 
shipments. "Balagh app" is not only used to file complaints about online stores, but is, also, used to handle issues related to physical stores. In order for citizen-reporting applications to work effectively, citizens have to be motivated to utilize and participate in the applications. Therefore, this research aims to answer the following research question:

What are the factors that contribute the most in motivating users to engage in citizen reporting applications to report commercial issues?

Therefore, this research will address the motivational factors behind the use of citizen reporting applications to report commercial issues. The research will apply the selfdetermination theory to identify the main factors that enhance citizens' engagement and participation in citizen-reporting applications.

\section{LITERATURE REVIEW}

\section{A. Citizens Sourcing and Reporting}

Zhao and Zhu [10] define crowdsourcing as a "collective intelligence system" that has three components: the organization, the crowd, and the platform. The organization in the context of this research is the government; the crowd component is the citizens; and the platform is the technology [11]. In the context of open government, crowdsourcing is also known as 'citizen-sourcing' or 'citizen-reporting' [12].

There is evidence that government agencies can utilize crowdsourcing to improve public services with lower costs, produce policy innovations, and engage larger numbers of public participants [13]. Estellés-Arolas and González-Ladrónde-Guevara [12] believe that 'crowdsourcing' itself is sometimes used in the same breadth as many other concepts such as 'co-creation', 'open innovation', and 'citizensourcing'. Governments use citizen-sourcing to engage citizens in information production that would help the government in its activities [14]. Therefore, governments can improve public services from the information generated by citizens via citizen reporting applications or online platforms. Citizen reporting is considered one of three sub-categories of citizen sourcing [14]. Citizens reporting allows citizens to report issues to governments and be part of the development process [15]. Several governments have developed citizen reporting applications for different purposes. In Switzerland, there is a citizen reporting application called "FixMyStreet". The aim of the "FixMyStreet" application is to allow citizens to report issues regarding the infrastructure of the city of Zurich to the local government [15]. The Portuguese government also developed an android mobile application called Citzens@City. This application allows citizens to report urban problems such as holes in the pavement, lack of public lighting, or poor access to wheelchairs to the local authority. Citizens can open the application and report the problem expressed by a subject, description, location, and optional picture of the reported spot [16].

The government of Saudi Arabia realized the value of citizen sourcing and citizen reporting applications as well. The Ministry of Interior launched a citizen reporting application called "Kulluna Amn". The purpose of "Kulluna Amn" is to make citizens part of the country's security systems by reporting incidents. Citizens are able to attach photos or videos with their reports and send them immediately to the concerned local authority. In addition, "Kulluna Amn" has a GPS system to determine the location of the incident. Similar to "Kulluna Amn", the Ministry of Commerce and Investment launched a citizen reporting application called "Balagh". "Balagh" enables customers to report any commercial violation through their smartphones with the possibility of attaching photos and locations of the violations. Customers can add the name of the stores, and type of the violations committed as well. The application additionally allows the customers to view the latest news and product recalls launched by the Ministry of Commerce and Investment. In order for the "Balagh" application to work efficiently and effectively, there is a need to motivate customers to participate and engage in the application. This paper will address the motivational factors behind user participation in reporting commercial violations using "Balagh".

\section{B. Motivational Theory}

One of the most important topics in psychology over many years has been the studying of human behaviours and the motivations behind such behaviours. Abraham Maslow intensively studied motivation and articulated his first theory in 1943 under the title of 'A Theory of human Motivation'. He illustrated in detail the human needs that motivate human behaviour. Motivation is the dynamic relationship between the individual and their surrounding environment that incites them to do something[17]. The topic of motivation has been studied from multiple angles. Although motivation is present in the actions of every individual, there are variations in the level and orientation of these motivations. The psychological literature differentiates between motives and motivation. According to Leimeister, et al. [18] "In the field of motivation psychology, a motive is seen as an individual's psychological disposition". Motivation is a combination of a person with specific motives and a situation, which gives certain incentives that trigger certain behaviour $[19,20]$. Motives are relatively stable over the lifespan of an individual and do not automatically lead to certain actions. Typically, an activator is needed to initiate behaviour.

The question that arises in this context is what motivates individuals to adopt new technologies and accept them. There are many models that already exist in the field of Information Technology Acceptance that investigates how individuals come to accept new adoptions of information system technologies. This line of models and research also looks into ways to motivate potential users of such systems. Each model explains user behaviour using a different set of various factors. Examples of such models include the Theory of Reasoned Action (TRA)[19]; Self-Determination Theory (SDT) [21], the Theory of Planned Behaviour (TPB) [20]; the Technology Acceptance Model (TAM) [22]; and the Extension of the Technology Acceptance Model (TAM2) [23]. One of the most prominent theories that discuss the concept of motivation is the Self-Determination Theory (SDT) [21]. This theory classifies motivation into two categories: intrinsic and extrinsic. From an intrinsic motivation perspective, individual behaviour is driven by the sake of enjoyment for the activity itself rather than the instrumental value of that activity. On the other side, from an 
extrinsic motivation perspective, the behaviour is done to attain some separable consequence, external prods, or reward [21]. In this research, the self-determination theory (SDT) will be applied and extended.

\section{Factors Behind user Participation}

There is a bulk of literature that examines the motivational factors that affect engagement in citizen-sourcing applications. For example, Alshehri, et al. [24] prove that performance expectancy, effort expectancy, and facilitating conditions have positive influences on user intention (i.e. motivation) to use egovernment services in general. The study also found that social influence to be insignificant in terms of predicting the behavioural intention to use e-government services.

Lin [25] examines extrinsic motivations (i.e. expected organizational rewards and reciprocal benefits) and intrinsic motivations (i.e. knowledge self-efficacy, and enjoyment in helping others) of employees' attitudes and behaviour towards knowledge sharing. The results demonstrate that employee knowledge-sharing attitudes and behaviours are significantly influenced by mainly three motivational factors: knowledge self-efficacy, reciprocal benefits, and enjoyment from helping others. The study finds that organizational rewards do not have any significant impact but reports that employee attitudes toward knowledge-sharing do significantly influence behavioural intentions.

Another study by Kumar, et al. [26] shows that the adoption of e-Government is directly influenced by both user characteristics and the website design. User characteristics include perceived risks that are related to the user's financial status, performance risk, data privacy and security. Another user characteristic that is found to be significant in the determination of e-government adoption is the perceived control over the process and the degree of the user's Internet literacy (i.e. the amount of time users are exposed to the Internet, the usage frequency, and the length of time spent in each visit). Furthermore, website design factors comprise the perceived ease of use and the perceived usefulness of the website as explained on the technology acceptance model. The study finds that the adoption rate can be enhanced significantly by the user's perception of the usefulness of the services or online information that is provided by the government. Nevertheless, the perceived usefulness is associated with the perceived ease of use [26]. Service delivery quality also has an impact on user satisfaction, which in turn influences the adoption of e-Government.

Abu-Tayeh, et al. [15] determines how local authorities can be greatly benefited from the use of citizen reporting in the context of smart city areas. The study investigates the ZWN cross-channel platform that aims to enhance civic engagement in Switzerland. It shows that factors such as self-concern and other-orientation (i.e. concern towards others' wellbeing) motivate citizens to voluntarily use the platform in order to support the government. Nonetheless, several essential issues should be taken into consideration as well, such as socioeconomic characteristics. For example, gender has been shown to influence the actual participation in citizen reporting systems (e.g. the average number of reports submitted by males and females can vary significantly).

\section{HyPOTHESES AND MODEL DEVELOPMENT}

The self-determination theory is a suitable theory for examining the motivational factors behind a user's adoption and use of citizen reporting applications. It allows for extending the traditional theory to include factors that might trigger both intrinsic and extrinsic motivations which in turn impact the individual's behavioural intention to use such applications. Engagement in citizen reporting applications can be either driven by an extrinsic motive, such as having a good personal image, expecting rewards, or maintaining better service quality for reporting such incidents; or driven by an intrinsic motive, such as having a sense of inner social responsibility or settling an issue related to self-concern. Therefore, it is hypothesis that:

H1: Extrinsic motivation positively influences users' behavioural intention to use citizen reporting applications.

$\mathrm{H} 2$ : Intrinsic motivation positively influences users' behavioural intention to use citizen reporting applications.

In the following subsections, we define each of the components of the extrinsic and intrinsic motivations and construct the corresponding hypotheses for the proposed model (see Fig. 1).

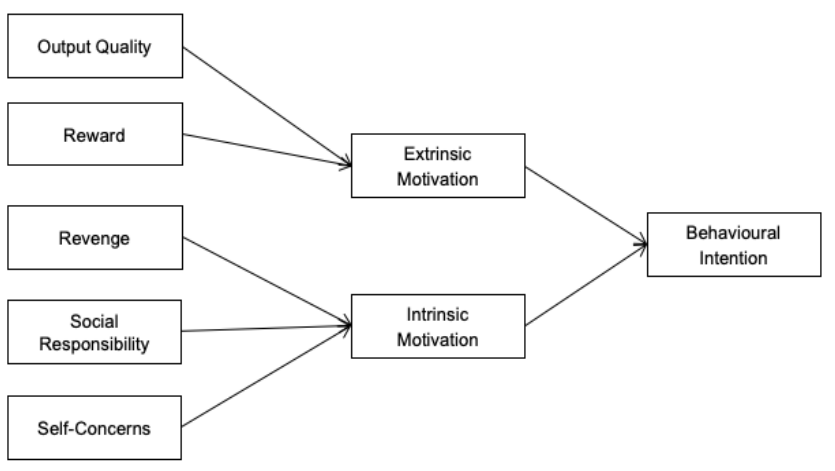

Fig. 1. Proposed Model.

\section{A. Extrinsic Motivation Factors}

Extrinsic motivation is closely related to the achievement and increase in value via the means of external benefits, monetary rewards, promotion, as well as other tangible rewards. It is thought of as a significant motivator in the literature relating to information systems. Davis, et al. [27], for instance, suggests that perceived usefulness is reflected by extrinsic motivation whilst intrinsic motivation relates to enjoyment.

1) Output quality: Output Quality refers to "an individual's perception about how well the system performs the tasks" [23]. Output quality in this context is the quality of services that are provided by governments to citizens. The government services can be enhanced effectively if citizens collaborate with their governments and participate in citizen reporting applications [15]. Output quality was found to influence the perceived usefulness as explained in TAM2 [23]. The perceived usefulness (PU) can generally be defined as "a 
measure of the individual's subjective assessment of the utility of an information technology in a specific task-related context" [23]. According to Venkatesh, et al. [28], perceived usefulness is a similar concept to extrinsic motivation. Therefore, we can conclude that the output quality will be one of the reasons that will influence extrinsic motivation toward using citizen reporting applications. In light of the aforementioned, we derive the following hypothesis.

H3: Output Quality positively influences a user's extrinsic motivation towards using citizen reporting.

2) Reward: Reward refers to the positive feedback as compensation or remuneration that can motivate citizens to perform the desired behaviours and to encourage them to share their knowledge about any system they used. Rewards can either be verbal or tangible. Verbal rewards, such as explicit positive performance feedback, are found to reinforce intrinsic motivation. Although some studies found that tangible rewards might weaken intrinsic motivation [17], several other studies found that monetary rewards encourage users and motivate them extrinsically to use the system [29, 30].

According to Assegaff, et al. [31], if employees believe they can receive organizational rewards by offering their knowledge, they will develop more positive attitudes towards knowledge sharing at VCoPs (Virtual Communities of Practices). The study, also, found that these rewards significantly affect employees' intentions to participate in VCoPs and share their knowledge. Accordingly, we imply that rewards will affect the extrinsic motivation and will have an indirect impact on behaviour intention to use citizens reporting applications. Therefore, we hypothesise that:

H4: Reward positively influences a user's extrinsic motivation towards using citizen reporting.

\section{B. Intrinsic Motivation Factors}

Intrinsic motivation is considered when tackling the success and adoption of information systems. Intrinsic motivation refers to the engagement in behaviour that is inherently satisfying or enjoyable [32]. Enjoyment influences intrinsic motivation positively to the extent that "the activity of using a specific system is perceived to be enjoyable in its own right, aside from any performance consequences resulting from system use" [33].

1) Revenge: Definitions of customer revenge in the literature are consistent to a greater or lesser extent. Customer revenge involves a customer exerting some harm to a firm in return for the perceived damages the firm has caused [34]. Previous studies show that a desire for revenge (i.e. a felt need to exert harm) increases the likelihood of "tangible" revenge behaviours [35]. An emphasis on a desire for revenge is important because users are not always able, depending on the context, to transform their desire into actions. This leaves room for the incorporation of moderators (such as power) that could explain when a desire for revenge produces real manifestations that are designed to harm the firm. Hence, we assume that revenge will have a major effect on individuals' intrinsic motivation and that it will indirectly affect individual's behavioural intention to use citizens reporting applications. Therefore, we hypothesis that:

H5: Revenge positively influences a user's intrinsic motivation towards using citizen reporting.

2) Self-concern: Abu-Tayeh, et al. [15] found that selfconcern and other-orientation are important factors that impact citizen reporting engagement. They also found that selfconcern has the strongest effect among other orientations on engagement. Self-concern can be defined as the inclination to base one's behaviour on the desire to protect and enhance one's self-interest. Citizens can be motivated to engage in citizen reporting because they expect to benefit from it. For example, when the government settles an issue, they had previously reported, because it personally irritated them. This demonstrate that citizens are largely self-concerned. Nevertheless, if citizens report infrastructure issues as they desire to help others, other orientations are the main motive. In a study done by De Dreu and Nauta [36], they state that selfconcern can be raised by setting higher aspirations. Research on social dilemmas has shown that people have higher selfconcern when potential outcomes are outlined as losses rather than gains. Therefore, we suggest that self-concern impacts an individual's intrinsic motivation which influences individuals' behavioural intention. Hence, we hypothesise that:

H6: Self-concern positively influences intrinsic motivation towards using citizen reporting.

3) Social responsibility: Social responsibility is considered as the desire for an individual to help others and participate in a positive way to provide benefits to the society. One of the means of social responsibility is the participation in crowdsourcing applications. Previous studies have shown that social responsibility is positively associated with individuals' engagement in citizen reporting [15].

The study of Razmerita, et al. [37] illustrated that altruism, i.e. the enjoyment of helping others, is the most important factor that impacts the frequency of knowledge sharing. Consequently, we will propose that social responsibility will affect individual's intrinsic motivation to use citizens reporting applications. Therefore, we hypothesis that:

H7: Social responsibility positively influences intrinsic motivation towards using citizen reporting.

\section{RESEARCH METHODOLOGY}

\section{A. Sample and Data Collection}

The aim of this study is to identify the factors that motivate citizens to engage in citizen reporting applications to report commercial issues. To test the proposed hypotheses, we select a sample of users from the citizen reporting mobile application "Balagh" (translation: "report app") in Saudi Arabia. The Balagh app enables citizens to report commercial violations or frauds. Users' intrinsic and extrinsic motivational factors 
toward the usage of this app were collected using a close-ended structured questionnaire. SmartSurvey was used to design the questionnaire then the link was distributed through online channels like emails, WhatsApp, and social media accounts. In order to examine the accuracy, meaningfulness, and clarity of the questionnaire, the questionnaire was pilot-tested and filled by 30 respondents who were chosen randomly. Thereafter, the survey was distributed to 500 individuals, and 297 responses were received. Table I shows the demographic information of the respondents.

\section{B. Measurements}

All of the 26 items used in this research were developed using items validated in prior studies and adapted to fit the purpose of this research. Measurements items used in this research and the source of these measurements are presented in Table II. Each factor that might influence the behavioural intention and motivate the citizens to engage with the Balagh App was measured by five-point Likert-scale questions (i.e. from strongly disagree " 1 " to strongly agree "5").

\section{Data Analytical Procedure}

The study uses the Partial Least Squares (PLS) method to analyse the collected data. The PLS path modelling is a variance-based Structural Equation Modelling (SEM) technique that is widely applied in many research fields such as: business and social research for its ability to model composites and factors. This makes it suitable for studying the adoption and engagement with new technology and an ideal method to tackle the higher-level statistical performance of the study. Therefore, this method of analysis was chosen due to its proven validity to test models and relationships as well as its usefulness in test models in the case of a limited number of participants [41].

The analysis was done using SmartPLS software version 3.3.2. for Mac to evaluate the measurements and test the structural models simultaneously. Using SmartPLS, two steps were taken to examine the model. The first step was confirming the reliability and validity. The second step was analysing the structural equation model to evaluate the hypotheses.

TABLE I. RESPONDENTS DEMOGRAPHIC INFORMATION $(\mathrm{N}=297)$

\begin{tabular}{|l|l|l|l|}
\hline Variable & Value & Frequency & Percentage \\
\hline Age & Under 18 & 7 & $2.4 \%$ \\
\hline & $18-24$ & 28 & $9.4 \%$ \\
\hline & $25-34$ & 76 & $25.6 \%$ \\
\cline { 2 - 4 } & $35-54$ & 153 & $51.5 \%$ \\
\hline Gender & Over 55 & 33 & $11.1 \%$ \\
\hline & Male & 40 & $13.5 \%$ \\
\hline Educational level & Female & 257 & $86.5 \%$ \\
\hline & High school & 66 & $22.2 \%$ \\
\hline & Bachelor degree & 187 & $63.0 \%$ \\
\hline & Master degree & 24 & $8.1 \%$ \\
\hline & PhD. & 6 & $2.0 \%$ \\
\hline & Other & 14 & $4.7 \%$ \\
\hline
\end{tabular}

TABLE II. MEASUREMENT ITEMS

\begin{tabular}{|c|c|c|}
\hline VBs & Items & Source \\
\hline 预 & $\begin{array}{l}\text { BI1: I am considering using this app to report } \\
\text { incidents. } \\
\text { BI2: I would seriously contemplate using this } \\
\text { app. } \\
\text { BI3: It is likely that I am going to use this app. } \\
\text { BI4: I am likely to make future reports using } \\
\text { this app. }\end{array}$ & \multirow{3}{*}{$\begin{array}{l}\text { Adapted from } \\
\text { Davis, et al. [27] } \\
\text { and Venkatesh, et } \\
\text { al. [28] }\end{array}$} \\
\hline : & $\begin{array}{l}\text { EM1: I find using this application useful. } \\
\text { EM2: Using this application enables me to } \\
\text { report commercial incidents more efficiently. } \\
\text { EM3: I can forward my commercial concerns } \\
\text { to local government directly. }\end{array}$ & \\
\hline 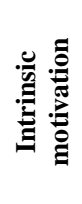 & $\begin{array}{l}\text { IM1: I participate in this application because I } \\
\text { think that this participation is interesting. } \\
\text { IM2: I participate in this application because } \\
\text { this participation is fun } \\
\text { IM3: I participate in this application because I } \\
\text { feel good when doing this reporting }\end{array}$ & \\
\hline 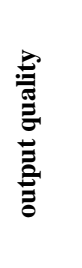 & $\begin{array}{l}\text { OQ1: The use of this application will improve } \\
\text { the quality of provided commercial services. } \\
\text { OQ2: The use of this application will } \\
\text { contribute to the development of commercial } \\
\text { services. } \\
\text { OQ3: Using this application will enhance the } \\
\text { overall quality and efficiency of the provided } \\
\text { commercial services. }\end{array}$ & $\begin{array}{l}\text { Adapted from } \\
\text { Compeau and } \\
\text { Higgins [38] }\end{array}$ \\
\hline 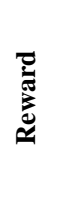 & $\begin{array}{l}\text { RW1: My willingness to participate in this } \\
\text { application would increase if there were } \\
\text { monetary rewards } \\
\text { RW2: I will really like to participate in this } \\
\text { application if I would receive monetary } \\
\text { rewards in return for my knowledge sharing. }\end{array}$ & $\begin{array}{l}\text { Adapted from } \\
\text { Wijnhoven, et al. } \\
{[39]}\end{array}$ \\
\hline : & $\begin{array}{l}\text { RV1: My feeling of anger towards violators } \\
\text { pushes me to use the application and report } \\
\text { them } \\
\text { RV2: I use this app to publicize the practices of } \\
\text { violators and punish them. } \\
\text { RV3: I submit a complaint via the application } \\
\text { to avenge violators }\end{array}$ & $\begin{array}{l}\text { Adapted from } \\
\text { Aquino, et al. [40] }\end{array}$ \\
\hline 㟒 & $\begin{array}{l}\text { SC1: I took part in "Balag" because I could } \\
\text { report problems that concerned me personally. } \\
\text { SC2: I took part in "Balag" because I could } \\
\text { report problems that prevented me from } \\
\text { fulfilling my needs } \\
\text { SC5: I participate in this application because I } \\
\text { believe that this kind of reporting is important } \\
\text { for me }\end{array}$ & $\begin{array}{l}\text { Adapted from } \\
\text { Abu-Tayeh, et al. } \\
{[15]}\end{array}$ \\
\hline 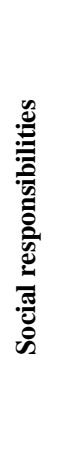 & $\begin{array}{l}\text { SR1: I took part in Balag application because it } \\
\text { gives me the opportunity to protect others from } \\
\text { commercial fraud. } \\
\text { SR2: I took part in this application because I } \\
\text { could help the community by doing so. } \\
\text { SR3: I want to contribute to the development } \\
\text { of the commercial services provided in my city } \\
\text { by using this application. } \\
\text { SR4: I would feel bad about myself if I don't } \\
\text { share information about commercial violations } \\
\text { with the relevant authorities. } \\
\text { SR5: I participate in this application because I } \\
\text { feel that this is something that I have to do it } \\
\text { for the society. }\end{array}$ & $\begin{array}{l}\text { Adapted from both } \\
\text { Abu-Tayeh, et al. } \\
\text { [15] and } \\
\text { Schmidthuber, et } \\
\text { al. [32] }\end{array}$ \\
\hline
\end{tabular}




\section{RESUlts}

\section{A. Measurement Model}

In this step, we present the assessment of the reliability and validity of the measurement model. Cronbach's alpha and composite reliability $(\mathrm{CR})$ were used to assess the reliability while convergent validity and discriminant validity were used to check the validity of our model. Table III shows 24 out of 26 indicators have factor loadings above 0.7 . Only two indicators, rewards and intrinsic motivation, have a lower factor loading. Intrinsic motivation has a factor loading of 0.665 while reward has a factor loading of 0.507 which, according to Hair, et al. [42], are still above the minimum acceptable threshold value of 0.5 for factor loadings. The t-values also demonstrate a satisfactory reliability level of all indicators as all the indicators are significantly linked with their corresponding constructs $(\mathrm{p}$ $<$ 0.001) [43]. Furthermore, Cronbach's alpha $(\alpha)$ of all variables exceeds the threshold of 0.7 [44] except for two factors (i.e. intrinsic motivation and revenge). Intrinsic motivation has a Cronbach's alpha $(\alpha)$ value of 0.669 while revenge has a value of 0.618 . According to Hair, et al. [45], any variable with Cronbach's alpha $(\alpha)$ value above 0.6 still shows acceptable level of internal consistency. Therefore, all of our constructs show a good level of internal consistency. Table III also shows that all composite reliability (CR) values are greater than the recommended value of 0.7 [43]. It also shows that the values of all the average variance extracted (AVE) of our constructs exceed the critical threshold value of 0.5 showing a good convergent validity [46]. Lastly, the correlation of the square root of AVE for all of the constructs, as shown in Table IV, are higher than their correlations with other constructs, proving the discriminant validity of our measurement model.

\section{B. Structural Model Assessment}

As the reliability and validity of our measurement model have been confirmed, we proceeded with testing of the structural model. This step is used to examine the relationship between variables and to assess the model's predictive capabilities. The significance of path coefficients and the R2 are the key criteria for assessing the structural model. The nonparametric bootstrapping procedure in the PLS analysis with 500 samples was performed to examine the structural models and to calculate the path coefficients and their significance levels.

As shown in Table $\mathrm{V}$, all of our hypotheses are supported except two hypotheses that are rejected. Extrinsic motivation has a positive significant relationship with behavioural intention $(\beta=0.553, \mathrm{t}=9.557, \mathrm{p}<0.001)$ and intrinsic motivation also has a positive significant relationship $(\beta$ $=0.220, \mathrm{t}=4.576, \mathrm{p}<0.000$ ) supporting both $\mathrm{H} 1$ and $\mathrm{H} 2$. In addition, output quality positively influences extrinsic motivation $(\beta=0.696, \mathrm{t}=18.940, \mathrm{p}<0.001)$ while reward has no significant relationship with extrinsic motivation $(\beta=$ $0.084, \mathrm{t}=1.215, \mathrm{p}<0.225)$; supporting $\mathrm{H} 3$ and rejecting $\mathrm{H} 4$. Intrinsic motivation is also found to be positively impacted by revenge $(\beta=0.384, t=6.273, p<0.001)$ and self-concern $(\beta=$
0.258, $\mathrm{t}=3.139, \mathrm{p}<0.001)$ supporting H5 and H6. On the other hand, social responsibility does not significantly impact intrinsic motivation $(\beta=0.258, \mathrm{t}=3.139, \mathrm{p}>0.121)$; rejecting H7. To determine the predictive power of our model, the value of $\mathrm{R}^{2}$ is used. $\mathrm{R}^{2}$ is a statistical measure that reports the variance in the dependent variable that can be explained by the independent variables. In general, the model managed to explain the variance in a user's behavioural intention by $45.6 \%$ $\left(\mathrm{R}^{2}=0.456\right)$. The identified extrinsic motivational factors, i.e. output quality and reward, were able to explain variance in users' extrinsic motivation by $49.9 \%\left(\mathrm{R}^{2}=0.499\right)$. On the other hand, revenge, self-concern, and social responsibility were able to explain variance in intrinsic motivation by $43 \%\left(\mathrm{R}^{2}=0.431\right)$. All $\mathrm{R}^{2}$ values are higher than 0.1 which is the minimum acceptable level as defined by [46]; indicating a good predictive power for our model. Fig. 2 and Table V summarize the analysis results.

TABLE III. The Measurement Model Statistics

\begin{tabular}{|c|c|c|c|c|c|c|}
\hline Variable & Items & Loading & T-value & $\alpha$ & CR & AVE \\
\hline \multirow{4}{*}{$\begin{array}{l}\text { Behavioural } \\
\text { Intention }\end{array}$} & BI1 & 0.809 & 31.809 & \multirow{4}{*}{0.848} & \multirow{4}{*}{0.897} & \multirow{4}{*}{0.686} \\
\hline & BI2 & 0.834 & 25.718 & & & \\
\hline & $\mathrm{BI} 3$ & 0.819 & 32.454 & & & \\
\hline & BI4 & 0.851 & 42.551 & & & \\
\hline \multirow{3}{*}{$\begin{array}{l}\text { Extrinsic } \\
\text { motivation }\end{array}$} & EM1 & 0.812 & 31.719 & \multirow{3}{*}{0.729} & \multirow{3}{*}{0.847} & \multirow{3}{*}{0.648} \\
\hline & EM2 & 0.788 & 26.573 & & & \\
\hline & EM3 & 0.815 & 29.125 & & & \\
\hline \multirow{3}{*}{$\begin{array}{l}\text { Intrinsic } \\
\text { motivation }\end{array}$} & IM1 & 0.665 & 9.473 & \multirow{3}{*}{0.669} & \multirow{3}{*}{0.797} & \multirow{3}{*}{0.569} \\
\hline & IM2 & 0.758 & 15.359 & & & \\
\hline & IM3 & 0.831 & 27.995 & & & \\
\hline \multirow{3}{*}{ output quality } & OQ1 & 0.845 & 35.881 & \multirow{3}{*}{0.820} & \multirow{3}{*}{0.893} & \multirow{3}{*}{0.736} \\
\hline & OQ2 & 0.850 & 36.877 & & & \\
\hline & OQ3 & 0.878 & 44.257 & & & \\
\hline \multirow{2}{*}{ Reward } & RW1 & 0.507 & 1.475 & \multirow{2}{*}{0.816} & \multirow{2}{*}{0.735} & \multirow{2}{*}{0.603} \\
\hline & RW2 & 0.974 & 3.007 & & & \\
\hline \multirow{3}{*}{ Revenge } & RV1 & 0.825 & 34.076 & \multirow{3}{*}{0.618} & \multirow{3}{*}{0.798} & \multirow{3}{*}{0.56} \\
\hline & RV2 & 0.723 & 16.144 & & & \\
\hline & RV3 & 0.710 & 15.628 & & & \\
\hline \multirow{3}{*}{ Self-concerned } & $\mathrm{SC} 1$ & 0.857 & 38.582 & \multirow{3}{*}{0.717} & \multirow{3}{*}{0.839} & \multirow{3}{*}{0.637} \\
\hline & $\mathrm{SC} 2$ & 0.713 & 15.983 & & & \\
\hline & $\mathrm{SC} 3$ & 0.816 & 22.547 & & & \\
\hline \multirow{5}{*}{$\begin{array}{l}\text { Social } \\
\text { responsibilities }\end{array}$} & SR1 & 0.831 & 39.190 & \multirow{5}{*}{0.863} & \multirow{5}{*}{.900} & \multirow{5}{*}{0.644} \\
\hline & SR2 & \begin{tabular}{|l}
0.798 \\
\end{tabular} & 24.692 & & & \\
\hline & SR3 & 0.778 & 20.510 & & & \\
\hline & SR4. & \begin{tabular}{|l|}
0.773 \\
\end{tabular} & 33.179 & & & \\
\hline & SR5 & 0.829 & 35.497 & & & \\
\hline
\end{tabular}


TABLE IV. DISCRIMINANT VALIDITY: SQUARE ROOT OF AVE

\begin{tabular}{|l|l|l|l|l|l|l|l|l|}
\hline Variables & BI & EM & IM & OQ & RV & RW & SC & SR \\
\hline Behavioural Intention & $\mathbf{0 . 8 2 8}$ & & & & & & & \\
\hline Extrinsic Motivation & 0.645 & $\mathbf{0 . 8 0 5}$ & & & & & & \\
\hline Intrinsic Motivation & 0.451 & 0.416 & $\mathbf{0 . 7 5 5}$ & & & & & \\
\hline Output Quality & 0.672 & 0.701 & 0.386 & $\mathbf{0 . 8 5 8}$ & & & & \\
\hline Revenge & 0.512 & 0.509 & 0.605 & 0.503 & $\mathbf{0 . 7 5 4}$ & & & \\
\hline Reward & -0.071 & -0.131 & 0.114 & -0.068 & 0.082 & $\mathbf{0 . 7 7 7}$ & & \\
\hline Self-concerned & 0.633 & 0.633 & 0.567 & 0.577 & 0.623 & 0.054 & $\mathbf{0 . 7 9 8}$ & \\
\hline Social Responsibilities & 0.758 & 0.750 & 0.487 & 0.728 & 0.555 & -0.143 & 0.640 & $\mathbf{0 . 8 0 2}$ \\
\hline
\end{tabular}

TABLE V. OVERVIEW OF THE HYPOTHESES TEST RESUlTS

\begin{tabular}{|c|c|c|c|c|c|}
\hline $\begin{array}{l}\text { Hypotheses } \\
\text { number }\end{array}$ & Hypotheses & $\beta$ & $\begin{array}{l}\text { T- } \\
\text { value }\end{array}$ & $\begin{array}{l}\text { P- } \\
\text { Values }\end{array}$ & $\begin{array}{l}\text { Supporte } \\
\text { d/ not } \\
\text { supported }\end{array}$ \\
\hline H1 & $\begin{array}{l}\text { Extrinsic Motivation } \\
\rightarrow \text { Behavioural } \\
\text { Intention }\end{array}$ & 0.553 & 9.557 & 0.000 & supported \\
\hline $\mathrm{H} 2$ & $\begin{array}{l}\text { Intrinsic Motivation } \\
\rightarrow \text { Behavioural } \\
\text { Intention }\end{array}$ & 0.220 & 4.576 & 0.000 & supported \\
\hline $\mathrm{H} 3$ & $\begin{array}{l}\text { Output Quality } \rightarrow \\
\text { Extrinsic Motivation }\end{array}$ & 0.696 & 18.940 & 0.000 & supported \\
\hline H4 & $\begin{array}{l}\text { Reward } \rightarrow \text { Extrinsic } \\
\text { Motivation }\end{array}$ & - & 1.215 & 0.225 & Rejected \\
\hline H5 & $\begin{array}{l}\text { Revenge } \rightarrow \text { Intrinsic } \\
\text { Motivation }\end{array}$ & 0.384 & 6.273 & 0.000 & supported \\
\hline H6 & $\begin{array}{l}\text { Self-concerned } \rightarrow \\
\text { Intrinsic Motivation }\end{array}$ & 0.258 & 3.139 & 0.002 & supported \\
\hline H7 & $\begin{array}{l}\text { Social } \\
\text { Responsibilities } \rightarrow \\
\text { Intrinsic Motivation }\end{array}$ & 0.109 & 1.553 & 0.121 & Rejected \\
\hline
\end{tabular}

\section{DISCUSSION AND CONCLUSION}

The results indicate that both extrinsic and intrinsic motivational factors influence a citizen's behavioural intention to report commercial incidents using citizens' reporting applications. It is found that extrinsic motivation is much more influential than intrinsic motivation, nonetheless. Citizens' extrinsic motivation is significantly influenced by output quality. However, rewards are found to have no significant influence on a citizen's extrinsic motivation to report commercial incidents. Mainly, citizens are more concerned about the output quality that results from their engagement with the citizens' reporting applications for them to be motivated to report commercial incidents. This result is aligned with previous studies, such as [23] and [27], which demonstrated that individuals will be more motivated and encouraged to use a system if they believe the system will help them achieve their desired outcomes. According to [47], it is important to keep citizens informed about the improvements and actions taken based on their reports so that they feel that their reports are taken seriously. On the other hand, though reward was expected to impact a user's extrinsic motivation to participate in the system, it was not found significant. Previous research studying the role of rewards on impacting users' extrinsic motivation in several other contexts is conflicted. Some studies, such as [29-31], found that rewards play a significant role in encouraging users to participate, while others such as [17], found no significant role in influencing users' extrinsic motivation but instead it may weaken users' intrinsic motivation to use the system. This indicates that government institutions should concentrate on emphasising the effectiveness of citizens' participation to report commercial incidents on improving the quality of delivering commercial services within the city rather than offering rewards in return for their participation.

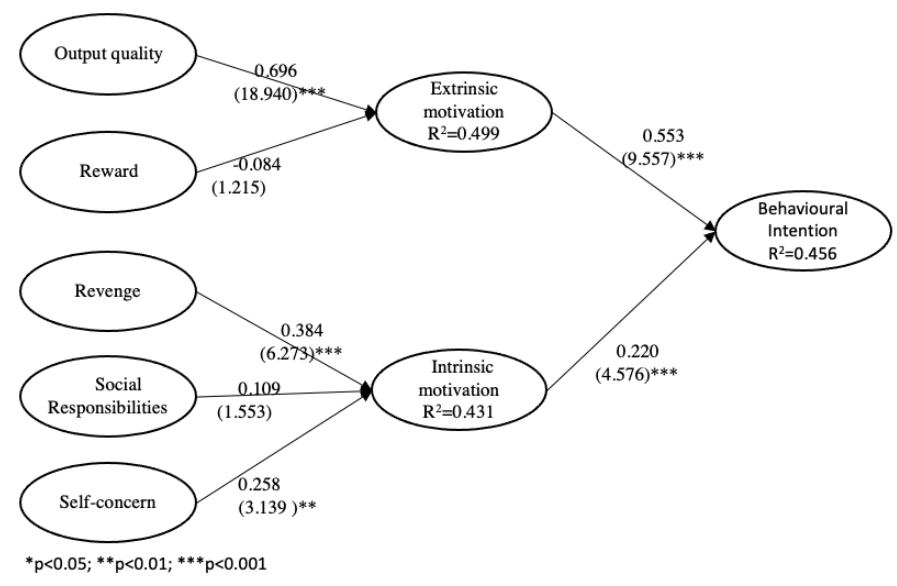

Fig. 2. The Results of the Empirical Study.

On the other hand, citizens' intrinsic motivation is found to be influenced by self-concern. This is supported by existing literature in the field, such as the work of [15], where they found that self-concern plays a significant role in the actual number of reports filed by an individual on a specific citizen's reporting application designed to enhance the infrastructure of the city. According to [48], individuals who are highly concerned about their self-gain are found to be more persistent contributors. As this study concentrates on reporting commercial incidents, it makes sense that citizens will report issues that impact them directly to solve their own problems and satisfy their needs. In alignment with this finding, we also found that revenge plays a significant role. When citizens personally face a problem with a certain commercial institution, such as shopping fraud or problems with their purchase, and the institution neglects their complaint, some of them feel anger and experience the urge to seek revenge. Thus, they feel that the use of citizen's reporting applications to report commercial incidents is a way for punishing the accountable commercial institution and gaining revenge. According to [34], typically customers feel that revenge is an appropriate response, especially after a series of failed amendment requests. Therefore, as citizens' reporting applications facilitate the process of restoring their rights and forcing the responsible commercial institution to solve the problem, it is justified that revenge plays a significant role in the context of this study. On the other hand, social responsibility is empirically found to have no influence on a user's intrinsic motivation. This contradicts the findings of [15] where they empirically found that other-orientation is a significant predictor of citizens' participation in citizens' 
reporting applications. This contradiction can be due to the differences in the context of the studies. The authors in [15] studied the motivational factors behind citizens' participation in reporting incidents related to infrastructure, while the context of this study is related to reporting commercial incidents. When reporting commercial incidents, citizens are mostly aware of the issues that impact them directly and are hardly aware of the issues that face others. Therefore, although social responsibility is important, its role in the context of this study is proven to be limited and of no significant impact. Hence, when reporting commercial incidents, citizens participate mainly for self-gain rather than being concerned about the quality of commercial services provided to others. Government institutions running this kind of applications should market their applications by emphasising the personal benefits that users can acquire as a result of using this kind of applications.

As per the above discussion, this study is limited to the context of citizens' reporting applications that are mainly designed to report commercial incidents. Therefore, its result cannot be generalised to other contexts. Future research should concentrate on studying the impact of context in moderating the motivational factors behind citizens' behavioural intention to use citizens' reporting applications. It will also be useful to investigate factors impacting the quality and accuracy of reported incidents and how these factors can be reflected in the design of citizens' reporting applications.

\section{REFERENCES}

[1] S. L. Alam, R. Sun, and J. Campbell, "Helping yourself or others? motivation dynamics for high-performing volunteers in GLAM crowdsourcing," Australasian Journal of Information Systems, vol. 24, pp. 1-25, 2020, doi: 10.3127/AJIS.V24I0.2599.

[2] M. Weiss, "Crowdsourcing Literature Reviews in New Domains," Technology Innovation Management Review, vol. 6, no. 2, pp. 5-14, 2016, doi: 10.22215/timreview963.

[3] D. Smith, M. Mehdi Gharaei Manesh, and A. Alshaikh, "How Can Entrepreneurs Motivate Crowdsourcing Participants?," Technology Innovation Management Review, vol. 3, no. 2, pp. 23-30, 2013, doi: 10.22215/timreview657.

[4] A. Desai et al., "Crowdsourcing a crisis response for COVID-19 in oncology," Nature Cancer, vol. 1, no. 5, pp. 473-476, 2020, doi: 10.1038/s43018-020-0065-z.

[5] "Coronavirus Disease 2019 (COVID-19) Situation Reports. April 1 2020," World Health Organization, 2020, vol. 2019. [Online]. Available: https://www.who.int/docs/default-source/coronaviruse/situationreports/20200324-sitrep-64-covid-19.pdf?sfvrsn=703b2c402\%0A https://www.who.int/docs/default-source/coronaviruse/situationreports/20200401-sitrep-72-covid-19.pdf?sfvrsn=3dd8971b_2.

[6] M. Barry, M. Al Amri, and Z. A. Memish, "Covid-19 in the shadows of MERS-CoV in the Kingdom of Saudi Arabia," 2020, vol. 10.

[7] A. Saudi Press, "Kingdom's government decides to suspend attendance at workplaces in all government agencies for period of (16) days except for health, security, military and electronic security cente," ed, 2020.

[8] A. Bashraheel, "Online shopping in Saudi Arabia jumps 400\% during coronavirus pandemic," in Arabnews, ed, 2020.

[9] A. Al-Awsat, "Saudi Arabia Investigates First Stockpiling Attempt," ed, 2020.

[10] Y. Zhao and Q. Zhu, "Evaluation on crowdsourcing research: Current status and future direction," Information Systems Frontiers, vol. 16, no. 3, pp. 417-434, 2014.

[11] K. Cupido and J. Ophoff, "A Model of Fundamental Components for an e-Government Crowdsourcing Platform," Electronic Journal of eGovernment, vol. 12, no. 2, pp. 141-156, 2014.
[12] E. Estellés-Arolas and F. González-Ladrón-de-Guevara, "Towards an integrated crowdsourcing definition," Journal of Information Science, vol. 38 , no. 2, pp. 189-200, 2012/04/01 2012, doi: $10.1177 / 0165551512437638$.

[13] P. Dutil, "Crowdsourcing as a new instrument in the government's arsenal: Explorations and considerations," Canadian Public Administration, vol. 58, no. 3, pp. 363-383, 2015, doi: https://doi.org/10.1111/capa.12134.

[14] D. Linders, "From e-government to we-government: Defining a typology for citizen coproduction in the age of social media," 2012, doi: 10.1016/j.giq.2012.06.003.

[15] G. Abu-Tayeh, O. Neumann, and M. Stuermer, "Exploring the Motives of Citizen Reporting Engagement: Self-Concern and Other-Orientation," Business \& Information Systems Engineering, 2018, doi: 10.1007/s12599-018-0530-8.

[16] A. M. Ribeiro, R. P. Costa, L. Marcelino, and C. Silva, "Citizens@City Mobile Application for Urban Problem Reporting," in ENTERprise Information Systems, Berlin, Heidelberg, M. M. Cruz-Cunha, J. Varajão, P. Powell, and R. Martinho, Eds., 2011// 2011: Springer Berlin Heidelberg, pp. 141-150.

[17] E. L. Deci, R. Koestner, and R. M. Ryan, "Extrinsic Rewards and Intrinsic Motivation in Education: Reconsidered Once Again," Review of Educational Researchl Spring, vol. 71, no. 1, pp. 1-27, 2001, doi: 10.3102/00346543071001001.

[18] J. M. Leimeister, M. Huber, U. Bretschneider, and H. Krcmar, "Leveraging Crowdsourcing: Activation-Supporting Components for ITBased Ideas Competition," Journal of Management Information Systems, vol. 26, no. 1, pp. 197-224, 2009/07/01 2009, doi: 10.2753/MIS07421222260108 .

[19] M. Fishbein and I. Ajzen, Belief, attitude, intention and behaviour: An introduction to theory and research. Reading, Mass: Addison-Wesley, 1975.

[20] I. Ajzen, "The theory of planned behavior," Organizational behavior and human decision processes, vol. 50, no. 2, pp. 179-211, 1991.

[21] E. L. Deci and R. M. Ryan, Intrinsic Motivation and Self-Determination in Human Behavior. Springer, 1985.

[22] F. D. Davis, R. P. Bagozzi, and P. R. Warshaw, "User acceptance of computer technology: a comparison of two theoretical models," Management science, vol. 35, no. 8, pp. 982-1003, 1989.

[23] V. Venkatesh and F. D. Davis, "A theoretical extension of the technology acceptance model: Four longitudinal field studies," Management science, vol. 46, no. 2, pp. 186-204, 2000.

[24] M. Alshehri, S. Drew, and R. AlGhamdi, "Analysis of citizens acceptance for e-government services: applying the UTAUT model," arXiv preprint arXiv:1304.3157, 2013.

[25] H. F. Lin, "Effects of extrinsic and intrinsic motivation on employee knowledge sharing intentions," Journal of Information Science, vol. 33, no. 2, pp. 135-149, 2007, doi: 10.1177/0165551506068174.

[26] V. Kumar, B. Mukerji, I. Butt, and A. Persaud, "Factors for Successful eGovernment Adoption : a Conceptual Framework," The Electronic Journal of e- Government, vol. 5, no. 1, pp. 63-76, 2007.

[27] F. D. Davis, R. P. Bagozzi, and P. R. Warshaw, "Extrinsic and intrinsic motivation to use computers in the workplace1," Journal of applied social psychology, vol. 22, no. 14, pp. 1111-1132, 1992.

[28] V. Venkatesh, M. G. Morris, G. B. Davis, and F. D. Davis, "User acceptance of information technology: Toward a unified view," Management Information Systems Quarterly, pp. 425-478, 2003.

[29] B. E. P. Thapa, B. Niehaves, C. E. Seidel, and R. Plattfaut, "Citizen involvement in public sector innovation: Government and citizen perspectives," Information Polity, vol. 20, pp. 3-17, 2015, doi: 10.3233/IP-150351.

[30] N. Shoemaker, "Extrinsic Rewards, Knowledge Sharing, and SelfDetermined Motivation," vol. 11, no. 3, pp. 99-114, 2014.

[31] S. Assegaff, Kurniabudi, and E. Fernando, "Impact of extrinsic and intrinsic motivation on knowledge sharing in virtual communities of practices," Indonesian Journal of Electrical Engineering and Computer Science, vol. 1, no. 3, pp. 619-626, 2016, doi: 10.11591/ijeecs.v1.i3.pp619-629. 
[32] L. Schmidthuber, D. Hilgers, T. Gegenhuber, and S. Etzelstorfer, "The emergence of local open government: Determinants of citizen participation in online service reporting," Government Information Quarterly, vol. 34, no. 3, pp. 457-469, 2017/09/01/ 2017, doi: https://doi.org/10.1016/j.giq.2017.07.001.

[33] C. M. Chao, "Factors determining the behavioral intention to use mobile learning: An application and extension of the UTAUT model," Frontiers in Psychology, vol. 10, pp. 1-14, 2019, doi: 10.3389/fpsyg.2019.01652.

[34] Y. Grégoire, D. Laufer, and T. M. Tripp, "A comprehensive model of customer direct and indirect revenge: Understanding the effects of perceived greed and customer power," Journal of the Academy of Marketing Science, vol. 38, no. 6, pp. 738-758, 2010, doi: 10.1007/s11747-009-0186-5.

[35] H. Zourrig, J.-C. Chebat, and R. Toffoli, "Consumer revenge behavior: A cross-cultural perspective," Journal of Business Research, vol. 62, no. 10, pp. 995-1001, 2009, doi: https://doi.org/10.1016/j.jbusres.2008.08.006.

[36] C. K. W. De Dreu and A. Nauta, "Self-Interest and Other-Orientation in Organizational Behavior: Implications for Job Performance, Prosocial Behavior, and Personal Initiative," in Journal of Applied Psychology vol. 94, ed, 2009, pp. 913-926.

[37] L. Razmerita, K. Kirchner, and P. Nielsen, "What factors influence knowledge sharing in organizations? A social dilemma perspective of social media communication," Journal of Knowledge Management, vol. 20, no. 6, pp. 1225-1246, 2016, doi: 10.1108/JKM-03-2016-0112.

[38] D. R. Compeau and C. A. Higgins, "Computer self-efficacy: Development of a measure and initial test," Mis Quarterly, vol. 19, no. 2, pp. 189-211, 1995.

[39] F. Wijnhoven, M. Ehrenhard, and J. Kuhn, "Open government objectives and participation motivations," Government Information Quarterly, vol. 32, no. 1, pp. 30-42, 2015, doi: 10.1016/j.giq.2014.10.002.

[40] K. Aquino, T. M. Tripp, and R. J. Bies, "How employees respond to personal offense: the effects of blame attribution, victim status, and offender status on revenge and reconciliation in the workplace," (in eng),
The Journal of applied psychology, vol. 86, no. 1, pp. 52-9, Feb 2001, doi: 10.1037/0021-9010.86.1.52.

[41] K. K.-K. Wong, "Partial Least Squares Structural Equation Modeling (PLS-SEM) Techniques Using SmartPLS," Marketing Bulletin, vol. 24, no. 1, pp. 1-32, 2013. [Online]. Available: http://marketingbulletin.massey.ac.nz/v24/mb_v24_t1_wong.pdf\%5Cnhttp://www.researc hgate.net/profile/Ken_Wong10/publication/268449353_Partial_Least_Sq uares_Structural_Equation_Modeling_(PLSSEM)_Techniques_Using_SmartPLS/links/54773b1b0cf293e2da25e3f3. pdf.

[42] J. F. Hair, W. C. Black, B. J. Babin, and R. E. Anderson, 7th, Ed Multivariate data analysis. Englewood Cliffs, NJ: Prentice Hall, 2009.

[43] R. P. Bagozzi, Y. Yi, and L. W. Phillips, "Assessing Construct Validity in Organizational Research," Administrative Science Quarterly, vol. 36, no. 3, pp. 421-458, 1991, doi: 10.2307/2393203.

[44] R. P. Bagozzi and Y. Yi, "On the evaluation of structural equation models," Journal of the Academy of Marketing Science, vol. 16, no. 1, pp. 74-94, 1988, doi: 10.1007/BF02723327.

[45] J. F. Hair, C. William, B. Babin, and R. Anderson, "Multivariate data analysis," ed: Upper Saddle River, NJ: Prentice Hall, 2010.

[46] R. P. Bagozzi, "Evaluating Structural Equation Models with Unobservable Variables and Measurement Error: A Comment," Journal of Marketing Research, vol. 18, no. 3, pp. 375-381, 1981, doi: $10.2307 / 3150979$.

[47] B. L. Bayus, "Crowdsourcing new product ideas over time: An analysis of the Dell IdeaStorm community," Management science, vol. 59, no. 1, pp. 226-244, 2013.

[48] M. C. Bolino and A. M. Grant, "The Bright Side of Being Prosocial at Work, and the Dark Side, Too: A Review and Agenda for Research on Other-Oriented Motives, Behavior, and Impact in Organizations," Academy of Management Annals, vol. 10, no. 1, pp. 599-670, 2016, doi: 10.5465/19416520.2016.1153260. 